Çukurova Üniversitesi Mühendislik Fakültesi Dergisi, 36(3), ss. 719-733, Eylül 2021

Cukurova University Journal of the Faculty of Engineering, 36(3), pp. 719-733, September 2021

\title{
Sürtünme Karıştırma Kaynağı ile Birleştirilen AISI 316 Paslanmaz Çelik ve Karbonlu Çelik Çiftlerinin Mekanik Özelliklerinin ve Mikroyapılarının İncelenmesi
}

\author{
Yeliz ALNAK* ${ }^{* 1}$, Ali ÖZER ${ }^{2}$, Vedat SAVAȘ ${ }^{3}$ \\ ${ }^{1}$ Sivas Cumhuriyet Üniversitesi, Teknoloji Fakültesi, Mekatronik Mühendisliği Bölümü, Sivas \\ ${ }^{2}$ Sivas Cumhuriyet Üniversitesi, Mühendislik Fakültesi, Metalürji Mühendisliği Bölümü, Sivas \\ ${ }^{3}$ Fırat Üniversitesi, Teknoloji Fakültesi, Makine Mühendisliği Bölümü, Elazı̆̆
}

Geliş tarihi: 21.04 .2021

Kabul tarihi: 13.09 .2021

Öz

Sürtünme karıştırma kaynağı, belirli bir hızda dönen bir pimin metaller arasında sürtünmesiyle oluşan ısıyı kullanarak, benzer veya benzer olmayan malzemeleri katı halde kaynaklamak için kullanılan bir katı hal kaynak tekniğidir. Kaynak, kaynak yapılacak malzemelerden daha sert olan ve tükenmeyen bir pim ile yapılır. Bu çalışmada AISI 316 östenitik paslanmaz çelik ve sade karbonlu çelikler sürtünme karıştırma kaynağı ile birleştirilmiştir. Birleştirilen çelik plakalar $3 \mathrm{~mm}$ kalınlığa, $60 \mathrm{~mm}$ genişliğe ve $120 \mathrm{~mm}$ uzunluğa sahiptir. Deneylerde omuz çap1 $16 \mathrm{~mm}$, pim uzunluğu 2,7 mm olan eşkenar üçgen profilli tungsten karbür uç kullanılmıştır. Sürtünme karıştırma kaynağı 710 dev/dak devir sayısı ve 63 mm/dak ilerleme hızında ve takıma $1,5^{\circ}$ açı verilerek gerçekleştirilmiştir. Kaynaklı bölgelerinin mikroyapı ve mekanik özellikleri incelenerek, en uyumlu kaynak çiftinin belirlenmesi amaçlanmıştır. Yapılan mekanik testlerin ve mikroyapı analizlerinin sonuçlarından, en uyumlu kaynak çiftinin AISI 316-AISI 1010 olduğu ortaya çıkmıştır. Mekanik testlerde AISI 316-AISI 1010 çelik çiftinin 618,81 MPa çekme değeri ile diğer kaynak çiftlerinden daha iyi olduğu görülmüştür. Mikroyapıları incelendiğinde tane boyutunun malzemenin mukavemetini büyük ölçüde etkilediği, özellikle büyük tanelerin görüldüğü yerlerde malzemenin mukavemetinin düştüğü gözlemlenmiştir.

Anahtar Kelimeler: Sürtünme karıştırma kaynağı, Paslanmaz çelik, Karbonlu çelik, Mekanik özellikler, SEM

\section{Investigation of Mechanical Properties and Microstructures of AISI 316 Stainless Steel and Carbon Steel Pairs Combined by Friction Stir Welding}

\begin{abstract}
Friction stir welding is a solid state welding technique used to weld similar or dissimilar materials in a solid state, using the heat generated by the friction of a pin rotating at a certain speed between metals. Welding is done with a non-consumable pin that is harder than the materials to be welded. In this study, AISI 316 austenitic stainless steel and plain carbon steels were joined by friction stir welding. Steel plates joined have a thickness of $3 \mathrm{~mm}$, a width of $60 \mathrm{~mm}$ and a length of $120 \mathrm{~mm}$. Tungsten carbide tip with an equilateral triangle profile with a shoulder diameter of $16 \mathrm{~mm}$ and a pin length of $2.7 \mathrm{~mm}$ was used in the
\end{abstract}

*Sorumlu yazar (Corresponding author): Yeliz ALNAK, ytas@cumhuriyet.edu.tr 
experiments. The friction stir welding was performed at a speed of $710 \mathrm{rpm}$ and a welding speed of $63 \mathrm{~mm} / \mathrm{min}$, at an tilt angle of $1.5^{\circ}$ to the tool. It is aimed to determine the most compatible weld pair by examining the microstructure and mechanical properties of the welded areas. From the results of the mechanical tests and microstructure analysis, it has been revealed that the most compatible welding pair is AISI 316-AISI 1010. In mechanical tests, it was seen that the AISI 316-AISI 1010 steel pair had the best value among other weld pairs with a tensile value of $618,81 \mathrm{MPa}$. When the microstructures were examined, it was observed that the grain size greatly affected the strength of the material, and the strength of the material decreased, especially where large grains were seen..

Keywords: Friction stir welding, Stainless steel, Carbon steel, Mechanical properties, SEM

\section{GíRiș}

Gelişen teknoloji ile birlikte endüstriyel uygulamalarda işlevselliği arttırmak adına pek çok farklı malzeme bir arada kullanılmaya başlanmıştır. $\mathrm{Bu}$ malzemelerin tek parça olarak üretilmesi mümkün olmadığı için ayrı ayrı üretilip daha sonra uygun bir birleştirme tekniği ile birleştirilmesi gerekmektedir. Birleştirme tekniklerinden biri olan kaynak, üretilmesi zor malzemelerden karmaşık parçaların meydana getirilmesine olanak sağlayan eşsiz bir yöntemdir. Üretim yöntemlerine alternatif olarak kullanılmayan kaynak, tamamlayıcı bir süreçtir [1].

Sürtünme karıştırma kaynak yöntemi, kaynak yapılacak levhanın uzunluğu boyunca yüksek hızda dönen bir pimin belirli bir hizda ilerletilmesi işlemidir. Birleştirme işleminde, kaynaklanacak malzemeden daha sert olan bir malzemeden yapılmış tükenmeyen bir pim kullanılır [2]. İş parçasında çok az çarpılma meydana gelmesi, kaynak bölgesinde mükemmel metalürjik özellikler, kaynak sırasinda ilave metal kullanılmaması, çatlak olmaması, farklı kalınlıktaki malzemelerin birleştirilebilmesi açısından oldukça faydalı bir kaynak yöntemidir [3]. Yüksek ergime sıcaklığına sahip metallerin birleştirilmesi için bu koşullarda sertliklerini koruyabilecek özel pimler ve güçlü kaynak makineleri gerekir [4].

İyi bir kaynak için, dönme hızı (devir sayısı), ilerleme hızı, dalma derinliği, eğim açısı, uç geometrisi, omuz çap1 gibi parametrelerin doğru belirlenmesi gerekir. $\mathrm{Bu}$ sayede karıştırma bölgesinde ince taneli yapılar ve iyi mekanik özellikler elde edilebilir [5].
Dönme ve ilerleme hızlarının değişken olarak alındığ 1 parametrelerle yapilan çalışmalardan Aktarer ve arkadaşları [6] sabit ilerleme hızı ve üç farklı takım dönme hızı kullanarak birleştirdikleri benzer olmayan dissimilar kaynakta en yüksek mukavemet değerinin ve en fazla uzamanın 1250 dev/dak dönme hızında gerçekleştiğini görmüşlerdir. Reynolds ve arkadaşları [7] sabit ilerleme hızı ve iki farklı dönme hızlarında similar kaynak birleştirmeleri yapmışlardır. Düşük devir sayıs1 ile yaptıkları kaynakta $\mathrm{mm}$ başına 1S1 girdisinin daha düşük olduğunu bulmuşlardır. Bundan dolayı kaynak merkezinde daha küçük tanecikli yapılar elde edildiğini belirtmişlerdir. Bozkurt ve Boumerzough [8] yalın halde (HSS), $\mathrm{CrN}$ ve AlTiN kaplı takım malzemesi kullanarak sürtünme karıştırma kaynağını gerçekleştirmişler. Sabit dönme hızı ve iki farklı ilerleme hızı kullandıkları birleştirmelerde en iyi kaynak bağlantılarını AlTiN ile kaplanmış takımla elde etmişlerdir.

Pim geometrilerine bakıldığında yine çok farklı geometriler ile başarılı birleştirmeler yapılmıştır. Başak ve arkadaşları [9] sabit ilerleme hızı ve dönme hızı ile birleştirdikleri kaynakta altı farklı tipte pim kullanmışlardır. En uygun birleştirmeyi üçgen vidalı uç ile elde etmişlerdir. Ayrıca çekme dayanımı ve darbe dayanım özellikleri üzerinde takım omuz çapının levha kalınlığı oranına etkisini araştıran Nathan ve arkadaşları [10] $5 \mathrm{~mm}$ kalınlığında HSLA çeliğini sürtünme karıştırma kaynağ 1 ile birleştirmişleridir. İlerleme ve dönme hızını sabit tutarak beş farklı omuz çapına sahip pim kullanmışlardır.

Başlangıçta düşük erime sıcaklı̆̆ına sahip alüminyum ve alaşımları sürtünme karıştırma 
kaynağıyla birleştirilmeye başlanmıştır. Yapılan çalışmalarda hem pim geometrileri hem de farklı devir sayıları ve ilerleme hılarında birleştirmeler yapılmıştır. Oluşan kaynak bölgelerinin mekanik özellikleri ve mikroyapıları incelenmiştir. Boz ve Kurt [11] Al 1080 alüminyum alaşımını farklı pim tasarımı kullanarak birleştirmişler ve kaynaklı bağlantıların mekanik özelliklerine etkilerini incelemişlerdir. En iyi birleştirmeyi 0,85 ve 1,10 hatveli pim ile elde etmişlerdir. Elangovan ve Balasubramanian [12] AA6061 alüminyum alaşımının kaynağı için düz silindirik, konik silindirik, dişli silindirik, üçgen ve kare olmak üzere beş farklı pim üzerinde çalışmışlardır. Bu beş takım profilinden kare profilli takımın diğer takımlara göre kusursuz kaynaklar ürettiğini belirtmişlerdir. Şık ve arkadaşları [13] AA2024 alüminyum alaşımını üç farklı devir sayısı, iki farklı ilerleme hızında birleştirmişlerdir. En yüksek sertlik, en yüksek çekme dayanımı ve en yüksek eğme yorulma dayanımı değerlerini 1500 dev/dak$200 \mathrm{~mm} / \mathrm{dak}$ parametresi ile kaynakladığ numunelerde gerçekleştiğini görmüşlerdir. Sabit ilerleme hızı ve sabit devir sayısı ile AA5251 alüminyum alaşımını birleştiren Hasçalık ve arkadaşları [14] beş farklı pim geometrisi kullanmışlardır. En mukavemetli birleştirmeyi kare piramit geometrisine sahip pim ile gerçekleştiğini belirtmişlerdir.

Daha sonra sürtünme karıştırma kaynağının alanı karbonlu çelikler, paslanmaz çelikler ve polimerlerde dahil olmak üzere çeşitli materyallere kadar genişlemiştir [22]. Fujii ve arkadaşları [15] IF steel, S12C, S35C olmak üzere üç farklı karbon çeliğini farklı ilerleme hızları ve sabit devir sayısında birleştirmişlerdir. Birleştirme sonrası bu çeliklerin mekanik özellikleri ve mikroyapılarını incelediklerinde kaynak koşullarının her üç çeliği de önemli ölçüde etkilediklerini görmüşlerdir. AISI 1018 karbonlu çeliği birleştiren Lienert ve arkadaşları [16] en büyük takım aşınmasının tam 1sınmamış soğuk metalin hareketi esnasında oluştuğunu belirtmişlerdir. Bunu önlemek için ön 1sıtma, düşük dalış değeri, ön delik uygulamaları yapılabileceğini belirtmişlerdir. Meran ve Canyurt [4] AISI 304 ostenitik paslanmaz çelik plakaları eşkenar üçgen uç profili kullanarak birleştirmişlerdir. Devir sayıları, ilerleme hızları, takım baskı kuvvetleri ve takım açılarının birleştirmeye etkisini araştırmışlardır. Maksimum mukavemeti 950 dev/dak devir sayıs1, $60 \mathrm{~mm} /$ dak ilerleme hızı, 9 kN'luk takım baskı kuvveti ve 1,5 derecelik eğim açısında elde etmişlerdir. AISI 304 plakayı Lakshminarayanan [17] ise konik uç profili kullanarak birleştirmiştir. Çalışmasında farklı ilerleme hızı, devir sayısı ve omuz çapı kullanarak optimum değeri elde etmeye çalışmıştır. En iyi sonuçları $441 \mathrm{dev} /$ dak devir sayısı, $118 \mathrm{~mm} / \mathrm{dak}$ ilerleme hızı ve 17,5 mm omuz çapında elde etmiştir. Yine AISI 304 çelik plakayı birleştiren Park ve arkadaşları [18] kaynak dikişinin mikroyapısını ve sigma fazı oluşumunu incelemişlerdir. Kaynak bölgesindeki içyapının alüminyumda elde edilen yapıya benzediğini gözlemlemişlerdir. Ayrıca sigma fazı oluşumuna rastlanmadığını belirtmişlerdir. Meran ve arkadaşları [19] birleştirdikleri AISI 304 paslanmaz çeliğinde kaynaklı bölgenin çekme mukavemetlerini, sertlik değerlerini ve mikroyapılarını incelemişlerdir. Ayrıca takım dalma açısının kaynak dikişinde önemli bir etkisinin olduğunu gözlemlemişlerdir. Bilgin ve Meran [20] farklı kaynak parametreleri kullanarak birleştirdikleri AISI 430 ferritik paslanmaz çeliğin birleştirilmesinde takım dönme ve ilerleme hızının etkilerini incelemişlerdir. İlerleme hızını sabit tutup devir sayılarını değiştirerek yaptıkları birleştirmelerde en iyi mekanik direnç değerini $1120 \mathrm{dev} / \mathrm{dak}$ devir sayısında elde etmişlerdir. Devir sayısını sabit tutup ilerleme hızlarını değiştirdiklerinde ise en iyi mekanik direnç değerini $125 \mathrm{~mm} /$ dak ilerleme hızında elde etmişlerdir. AISI 409 ferritik paslanmaz çeliği birleştiren Cho ve arkadaşları [21] birleştirme işleminde dişbükey karıştırıcı uç kullanmışlardır. Karıştırma bölgesinde oldukça ince taneli bir mikroyapı elde etmişlerdir.

Ayrıca bu gibi benzer (similar) metallerin yanı sıra benzer olmayan (dissimilar) metallerde sürtünme karıştırma kaynağı ile birleştirilmiş başarılı sonuçlar elde edilmiştir. Örneğin Çakır ve Çelik [23] Al 5754-Cu malzeme çiftini farklı takım dönme ve ilerleme hızlarında, 0 ve $1 \mathrm{~mm}$ takım 
konumlandırması yaparak sürtünme karıştırma kaynağı ile birleştirmişlerdir. Karıştırıcı ucu bakıra nazaran daha yumuşak olan alüminyum tarafına $1 \mathrm{~mm}$ kaydırarak deneylerini gerçekleştirdiklerinde daha iyi mekanik değerler elde ettiklerini ifade etmişlerdir. Kimapogon ve Watanabe [24], alüminyum alaşımı ile düşük karbonlu çelik plakayı birleştirmişlerdir. En iyi dayanıma sahip kaynak dikişlerini, tabandan 0,2 mm mesafede olduğu pim uzunluğunda elde etmişlerdir. Aghaei ve Dehghani [25], çalışmalarında, sürtünme karıştırma kaynağı ile birleştirilen Monel 400 ve AISI 316 paslanmaz çeliğin mikroyapı ve mekanik özelliklerine dönme ve ilerleme hızlarının etkilerini araştırmışlardır. Kusursuz kaynakları, ilerleme hızı 50 ila 100 $\mathrm{mm} /$ dak olan $400 \mathrm{dev} /$ dak hızında elde etmişlerdir. Jafarzadegan ve arkadaşları [5], AISI 304 ile St37 çeliğini sabit ilerleme hızında, iki farklı takım dönme hızlarında ve takıma 3 derecelik açı vererek sürtünme karıştırma kaynağı ile birleştirmiş ve kaynak mikroyapısı incelemişlerdir. Kaynak alanında ana metaller dışında dört farklı bölge bulmuşlardır. Yine Jafarzadegan ve arkadaşları [26], AISI 304 ile St37 çeliğini sabit ilerleme ve takım dönme hızında ve birleştirmişler, sürtünme karıştırma kaynağı sırasında oluşan yüksek sıcaklık ve deformasyonun St37 karbon çeliğindeki östenitin yeniden kristalleşmesine sebep olduğunu, bu taneciklerin sürtünme karıştırma kaynağından sonra soğuyarak ince ferrit ve perlite dönüştügüüü belirtmişlerdir. Metadinamik yeniden kristalleşmenin 304 paslanmaz çelik östenit tanelerinde oluştuğunu ve karıştırma bölgesinde tane küçülmesine neden olduğunu ileri sürmüşlerdir. Karıştırma bölgesinin sertliğinin, her iki çeliğin karıştırma bölgesinde tane küçülmesine bağlı St37 temel metalinden daha yüksek olduğunu tespit etmişlerdir. Kaynağın, St37 çeliğine göre daha yüksek mukavemet ve sünekliğe sahip olduğunu ve enine çekme örneklerinin kırılmasının St37 çeliğinde gerçekleştiğini görmüşlerdir. Sharma ve Dwivedi [27], tavlama işlemine tabi tuttukları yapı çeliği ve ferritik paslanmaz çeliği birleştirmişlerdir. Çekme deneyi sonrasında enine kaynak numunesinin gerilme mukavemetinin, yap1 çeliği ana metalinden daha yüksek, ferritik paslanmaz çelik ana metalinden daha düşük olduğunu, boyuna kaynak numunesinin çekme mukavemetinin ise her iki ana metalden çok daha yüksek olduğunu görmüşlerdir.

$\mathrm{Bu}$ çalışmada, korozyona dayanıklı ve yüksek mukavemetli malzemeler olan östenitik paslanmaz çelikler (AISI 316) ile karbonlu çelikler (AISI 1010, AISI 1030, AISI 1050 ve AISI 1070) uygun çalışma koşullarında kullanılmak üzere sürtünme karıştırma kaynak yöntemiyle birleştirilmişlerdir. Dolayısıyla düşük maliyetli ve ara yüzey uyumluluğu (mukavemet, sertlik, yüzey kalitesi) yüksek olan malzemeler elde edilmeye çalışılmıştır. Bu amaçla, östenitik paslanmaz çelik (AISI 316) ve sade karbonlu çelikler (AISI 1010, AISI 1030, AISI 1050 ve AISI 1070) üniversal freze tezgâhında $710 \mathrm{dev} /$ dak devir sayısı ve $63 \mathrm{~mm} /$ dak ilerleme hızında birleştirilmiştir. Kaynaklı bölgelerinin mikroyapı ve mekanik özellikleri incelenmiş, en uyumlu kaynak çifti belirlenmeye çalışılmıştır.

\section{MATERYAL VE METOD}

$\mathrm{Bu}$ çalışmada östenitik paslanmaz çelik ve sade karbonlu çelikler sürtünme karıştırma kaynağı ile birleştirilmiştir. Çelik plakalar $3 \mathrm{~mm}$ kalınlığa, 60 $\mathrm{mm}$ genişliğe ve $120 \mathrm{~mm}$ uzunluğa sahiptir. Ana metallerin kimyasal bileşimleri Çizelge 1'de verilmiştir.

Çizelge 1. AISI 316 ostenitik paslanmaz çelik ve karbonlu çeliklerin kimyasal bileşimi

\begin{tabular}{|c|c|c|c|c|c|c|c|}
\hline \multirow{2}{*}{ Malzemeler } & \multicolumn{7}{|c|}{ Kimyasal bileşim } \\
\cline { 2 - 8 } & $\mathrm{C}$ & $\mathrm{Cr}$ & $\mathrm{Ni}$ & $\mathrm{Si}$ & $\mathrm{Mn}$ & $\mathrm{P}$ & $\mathrm{S}$ \\
\hline AISI 316 & 0,03 & 16,967 & 10,023 & - & 0,993 & - & - \\
\hline AISI 1010 & 0,119 & 0,017 & 0,018 & 0,087 & 0,495 & 0,017 & 0,013 \\
\hline AISI 1030 & 0,306 & 0,029 & 0,025 & 0,026 & 0,512 & 0,032 & 0,018 \\
\hline AISI 1050 & 0,538 & 0,029 & 0,027 & 0,035 & 0,389 & 0,115 & 0,003 \\
\hline AISI 1070 & 0,659 & 0,029 & 0,024 & 0,049 & 0,559 & 0,019 & 0,02 \\
\hline
\end{tabular}


Deneylerde kullanılan plakalara karıştırıcı ucun malzeme ile temasında yüke maruz kalmaması için birleşme noktasını ortalayacak şekilde $7 \mathrm{~mm}$ çapında bir delik açılmıştır. Şekil 1'de görüldüğü gibi omuz çap1 $16 \mathrm{~mm}$, pim uzunluğu 2,7 mm olan eşkenar üçgen profilli tungsten karbür uç kullanılmıştır. Takım açısı $1,5^{\circ}$ dir.

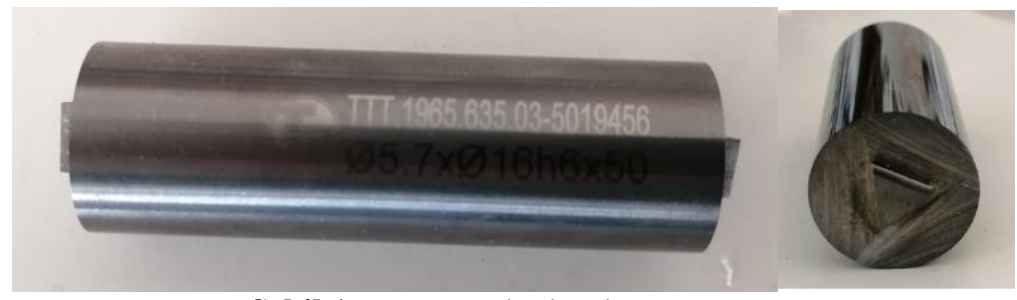

Şekil 1. Tungsten karbür karıştırıcı uç

Deneyler iki aşamada gerçekleştirilmiştir. İlk aşamada paslanmaz çelik farklı devir sayıları ve ilerleme hızları kullanılarak kendisi ile birleştirilmiş, 710 dev/dak devir sayısı, $63 \mathrm{~mm} / \mathrm{dak}$ ilerleme hızındaki kaynak parametrelerinde malzemeler homojen olarak karışmış, optimum mekanik ve mikroyapı özellikleri elde edilmiştir. Deneylerin ikinci aşaması olan paslanmaz çeliksade karbonlu çelik çiftlerinin kaynaklanmasına $710 \mathrm{dev} /$ dak devir sayısı, $63 \mathrm{~mm} /$ dak ilerleme hızı ile devam edilmiştir.

Kaynağın mekanik özellikleri, çekme, çentik darbe ve mikrosertlik deneyleri yapılarak incelenmiştir. Çekme deneyleri için numunelere, $1 \mathrm{~mm} / \mathrm{dak}^{\prime} \mathrm{l} \mathrm{k}$ çekme hızı ile çekme kuvveti uygulanmıştır.

Mikrosertlik incelemesi sürtünme karıştırma kaynağı ile birleştirilen malzemelerin kaynak bölgelerinden alınan metalografi numunelerinin kaynak bölgesi boyunca normal metal, isıdan etkilenmiş kaynak metali bölgesi olarak $1,5 \mathrm{~kg}$ yük altında 15 sn bekletilerek, $1 \mathrm{~mm}$ aralıklarla ilerletilip mikrosertlik testine tabi tutularak yapılmıştır. Çentik darbe deneyi oda sıcaklığında gerçekleştirilmiştir.

Kaynağın mikroyapısı Optik Mikroskop (OM, Nikon Eclipse L150) ve Taramalı Elektron Mikroskobu (SEM, TESCAN MIRA3 XMU) ile incelenmiştir. Optik Mikroskopta incelemek için ilk önce kaynaklı numuneye zımparalama ve parlatma işlemi yapılmıştır. Daha sonra \%65'lik nitrik asitten (HNO3) $5 \mathrm{ml}$, \%99,6'lık saf alkolden $95 \mathrm{ml}$ karıştırılarak 100 ml'lik stok dağlama çözeltisi hazırlanmıştır. Daldırma usulüyle 3 sn tüm numune daldırılıp bekletilerek derhal saf su ve alkol ile temizlenmiştir. Kurulandıktan sonra mikroskopta incelenmek üzere hazır hale getirilmiştir. Sürtünme karıştırma kaynağ 1 ile birleştirilen malzemeler hem yüzey morfolojisi, hem elementel dağılım için hem de çekme, çentik darbe ve kayma deneylerine tabi tutulduktan sonra bu deneylerden elde edilen kirık yüzeyler taramalı elektron mikroskobu (SEM) ile incelenmiştir.

Kaynak esnasında isınma soğuma şartlarından dolayı oluşabilecek yeni fazlar ve $\mathrm{Fe}$ için genlemeden dolayı oluşacak faz kaymaları ve safsızlıkların da faz analizi X ışınları difraksiyonu ile gerçekleştirilmiştir.

\section{SONUÇ VE TARTIŞMALAR}

\subsection{Mekanik Deney Sonuçları}

\subsection{1. Çekme Deneyi}

AISI 316-AISI 10X0 serisi çekme değerleri Şekil 2'de görülmektedir. Grafikler incelendiğinde çekme gerilmesi 618,81 MPa değerine sahip AISI 316-AISI 1010 kaynak çiftinin en iyi çekme değerine sahip olduğu görülmektedir. Bunu 583,58 MPa çekme gerilmesi değeri ile AISI 316-AISI 1030 kaynak çifti, daha sonra 532,69 MPa çekme değeri ile AISI 316-AISI 1050 kaynak çifti takip etmektedir. Son olarak 423,79 $\mathrm{MPa}$ çekme gerilmesi ile AISI 316-AISI 1070 kaynak çifti en düşük çekme gerilmesi değerine sahiptir. 
Sürtünme Karıştırma Kaynă̆ı ile Birleştirilen AISI 316 Paslanmaz Çelik ve Karbonlu Çelik Çiftlerinin Mekanik Özelliklerinin ve Mikroyapılarınin İncelenmesi

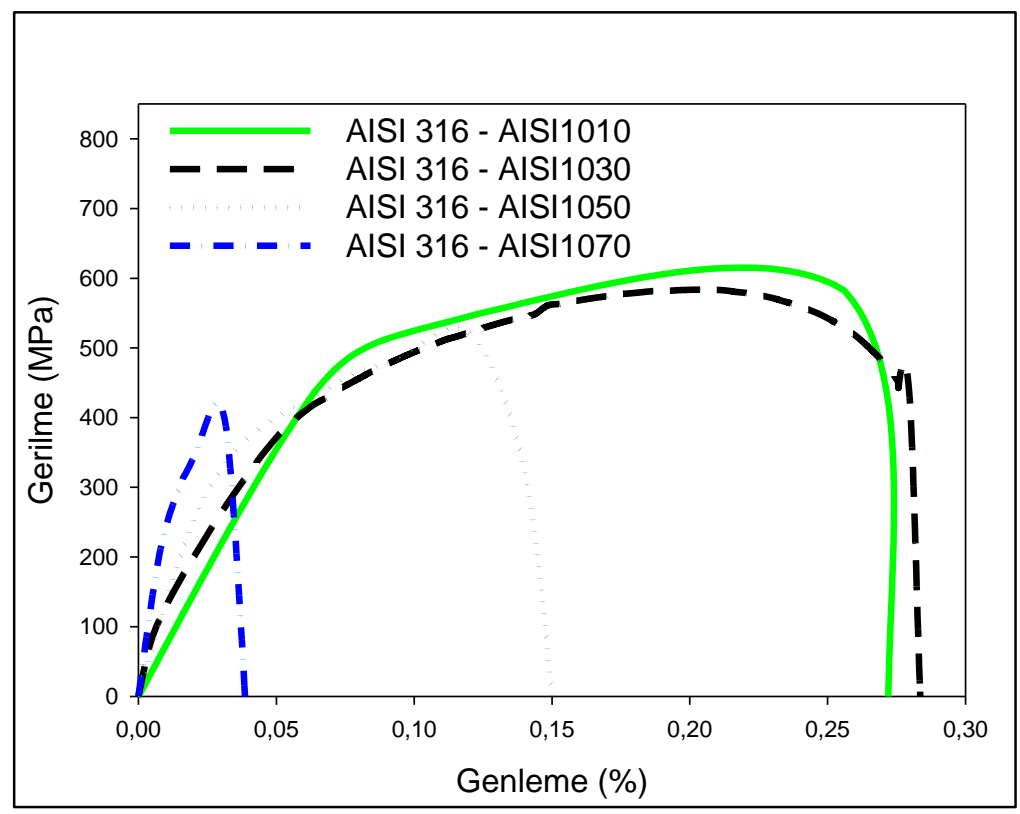

Şekil 2. AISI 316-AISI 10X0 serisi çekme değerleri

AISI 316-AISI 10X0 serisi kayma gerilmesi değerleri Şekil 3'te görülmektedir. Grafikler incelendiğinde en iyi kayma gerilmesi değeri AISI 316-AISI 1010 kaynak çiftine ait olup 582,74 MPa'dır. Bu değeri 529,52 MPa ile AISI 316-AISI
1030 kaynak çifti ve 498,03 MPa kayma gerilmesi değeri ile AISI 316-AISI 1050 kaynak çifti izlemektedir. Çekme gerilmesi değerinde olduğu gibi en düşük kayma gerilmesi değeri AISI 316AISI 1070 kaynak çiftine ait olup 311,94 MPa'dır.

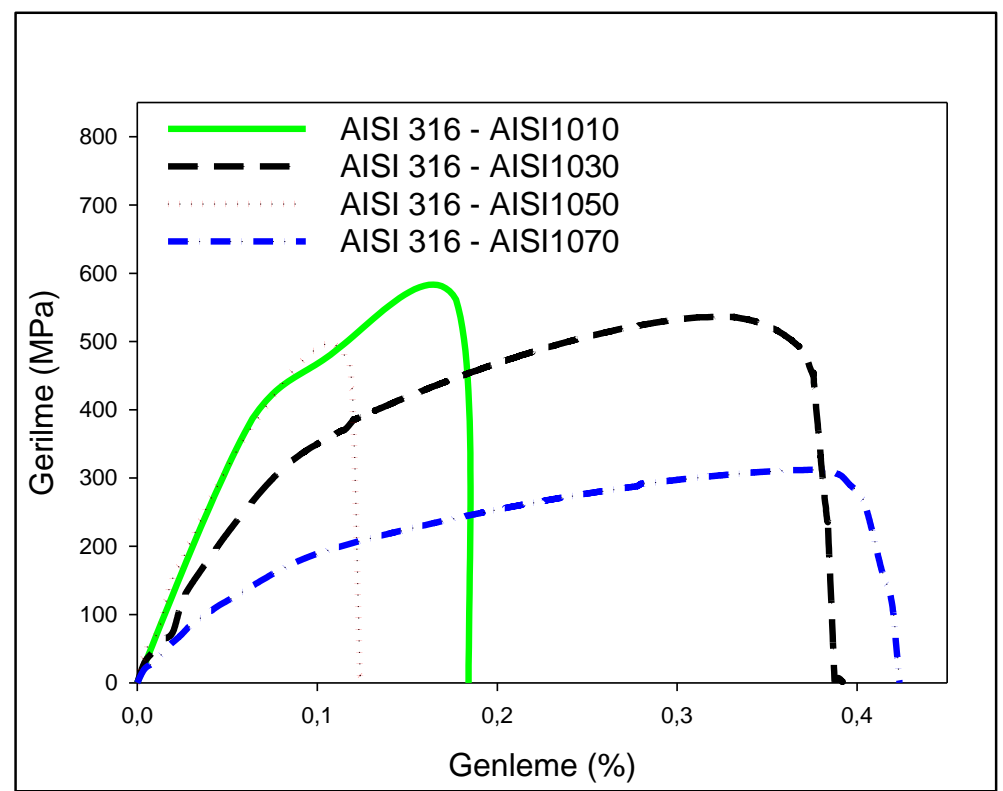

Şekil 3. AISI 316-AISI 10X0 serisi kayma değerleri 
Çekme ve kayma gerilmesi değerlerine baktığımızda AISI 316-AISI 1010 kaynak çiftinin en yüksek, AISI 316-AISI 1070 kaynak çiftinin en düşük gerilme değerlerine sahip olduğu görülmektedir.

En düşük gerilme değerine sahip olan AISI 1070 karbonlu çeliğinin diğer karbonlu çeliklere göre karbon oranın fazla olması nedeniyle perlitik yapıya en yakın çeliktir. İçerisinde daha fazla karbon içermesinden dolayı elementlerin geçişine izin vermemesi sebebiyle mekanik tutunmasının diğer karbonlu çeliklere göre daha kötü olduğu, bu nedenle en düşük mukavemetinde bu kaynak çiftinde çıktığg düşünülmektedir.

Diğer taraftan AISI 316 çeliğinin yüksek miktardaki alaşım elementine karşılık AISI 1010 karbonlu çeliğinde alașım elementinin olmaması, 1010 çeliğine difüze olan element miktarını attırmaktadır. Aynı zamanda 316 ve 1010 çeliklerinin sertliklerinin hemen hemen aynı olması ve 1010 çeliğinin içine difüze edebilen element miktarının fazla olması nedeniyle AISI 316-AISI 1010 kaynak çiftinin mukavemetinin diğer kaynak çiftlerine göre daha iyi çıktığı düşünülmektedir.

\subsection{1. Çentik Darbe Deneyi}

AISI 316-AISI 10X0 serisinde 19,5 J ile en yüksek kırılma enerjisine sahip AISI 316-AISI 1010 çelik çifti diğerlerine göre daha sünek davranış göstermektedir. Şekil 4'te çentik darbe deney sonuçları grafik halinde verilmiştir.

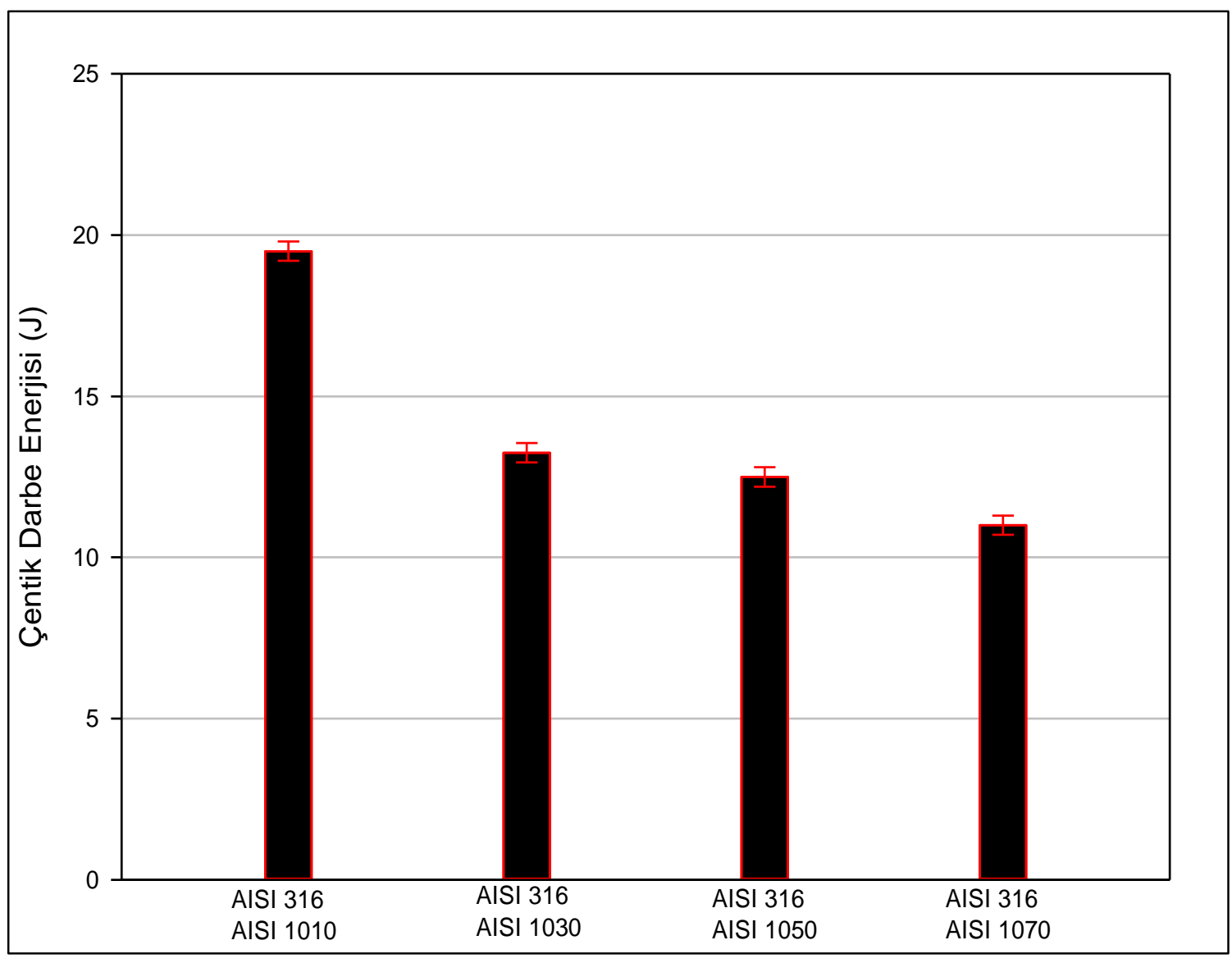

Şekil 4. Çentik darbe deney sonuçları grafikleri 
Sürtünme Karıştırma Kaynağı ile Birleştirilen AISI 316 Paslanmaz Çelik ve Karbonlu Çelik Çiftlerinin Mekanik Özelliklerinin ve Mikroyapılarının İncelenmesi

\subsubsection{Mikrosertlik Deneyi}

Şekil 5'teki grafikte her iki tarafın $1 \mathrm{~cm}$ civarındaki yerlerinde kaynak bölgesi oluşmuştur. Bu bölgenin solunda ve sağında malzemelerin kendi sertliklerinin olduğu görülmektedir. Orta bölgedeki
2 cm'lik kısımdaki kaynak bölgesinde intermetalik birikme ve $\mathrm{Fe}-\mathrm{Cr}$, Fe-Ni ve $\mathrm{Cr}-\mathrm{Ni}$ alaşımım sertleşmesinden dolayı kaynak bölgesindeki sertliğin yükseldiği görülmektedir. 316-1010 çeliklerinin sertlikleri $550-780 \quad \mathrm{~kg} / \mathrm{mm}^{2}$ seviyelerindedir.

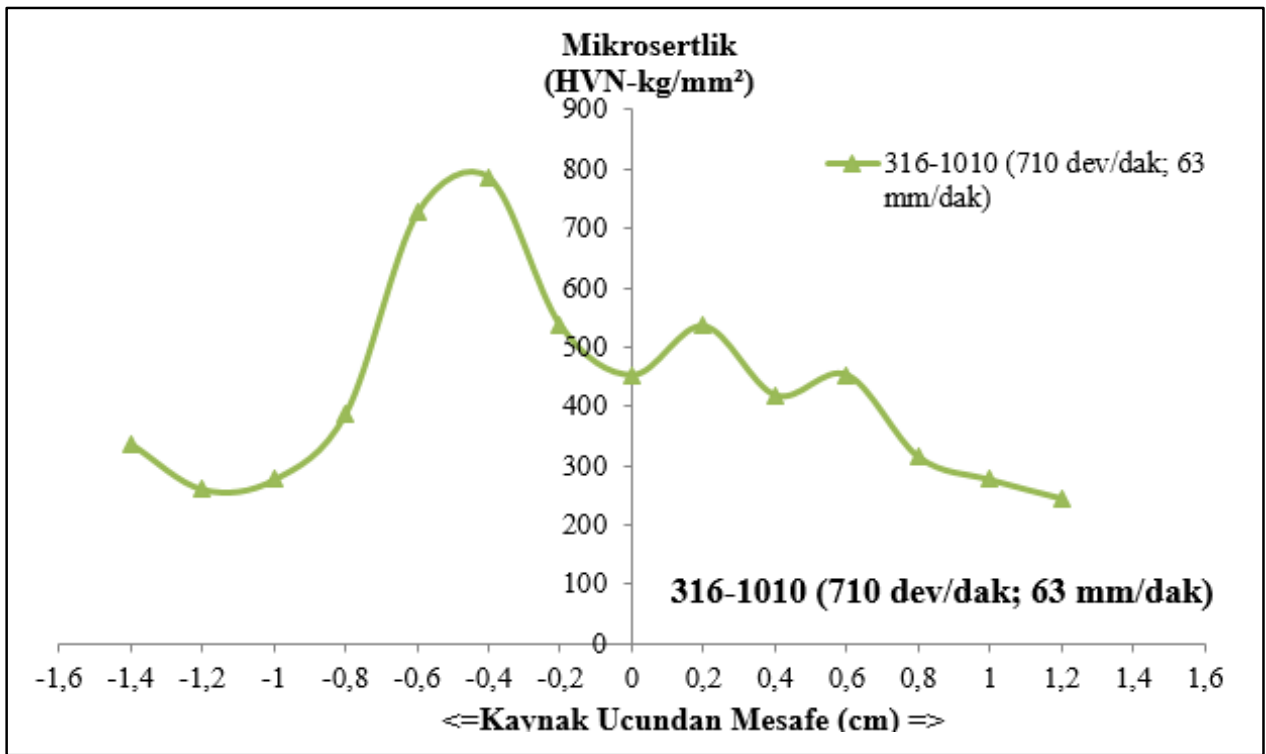

Şekil 5. 316-1010 çelik çiftinin mikrosertlik değeri

\subsection{Mikroyapı Deney Sonuçları}

Mikroyapı deney sonuçlarında kaynaklı bölgeler optik mikroskopta, çekme, kayma ve çentik darbe deneylerinden elde edilen kırık yüzeyler taramalı elektron mikroskobunda (SEM) incelenmiş ve XRD ile faz analizleri yapılmıştır.

\subsubsection{Optik Mikroskop}

Sürtünme karıştırma kaynağı ile birleştirilen numunelerin mikroyapıları optik mikroskopta incelenmiştir. Şekil 6'da AISI 316-AISI 10X0 kaynak çiftlerinin optik mikroskop görüntüleri verilmiştir.

AISI 1010 çeliğinin görüldüğü Şekil 6.a' da koyu gri görünen yerlerin perlit, açık renkte görülen yerlerin ise ferrit olduğu düşünülmektedir. Şekil 6.b'de paslanmaz çelikten karbonlu çeliğe doğru karıştırma bölgelerinin olduğu kaynak bölgesinin orta kısmı görülmektedir. Şekil 6.c'de paslanmaz çeliğin içerisine karbonlu çelikteki perlit ve ferritin gruplar halinde karıştığ görülmektedir. Şekil 6.d'de ise yapının tamamen paslanmaz çelik olduğu gözlemlenmektedir.

Şekil 6.e'de AISI 1030 karbonlu çelik görülmekte, Şekil 6.f'de kaynak bölgesine doğru ilerledikçe paslanmaz çeliğin içerisinde 1030 karbonlu çeliğin varlığı göze çarpmaktadır. Burada yüksek miktarda Krom ve Nikel içeren paslanmaz çelik ile karbonlu çelikte fazların birbiri içinde çözünmediği gözlemlenmektedir. Ayrıca yüzeyde siyah renkte görülen bölgelerin 1sıdan dolayı çökelmiş karbür partiküllerinin olduğu düşünülmektedir. Şekil 6.g'de karıştırıcı ucun dönmesinden kaynaklı malzemeler birbiri içine akmış durumda, orta kısımların 1030, kenarların ise paslanmaz çelik olduğu, Şekil 6.h'de ise paslanmaz çelik yap1 görülmektedir. 


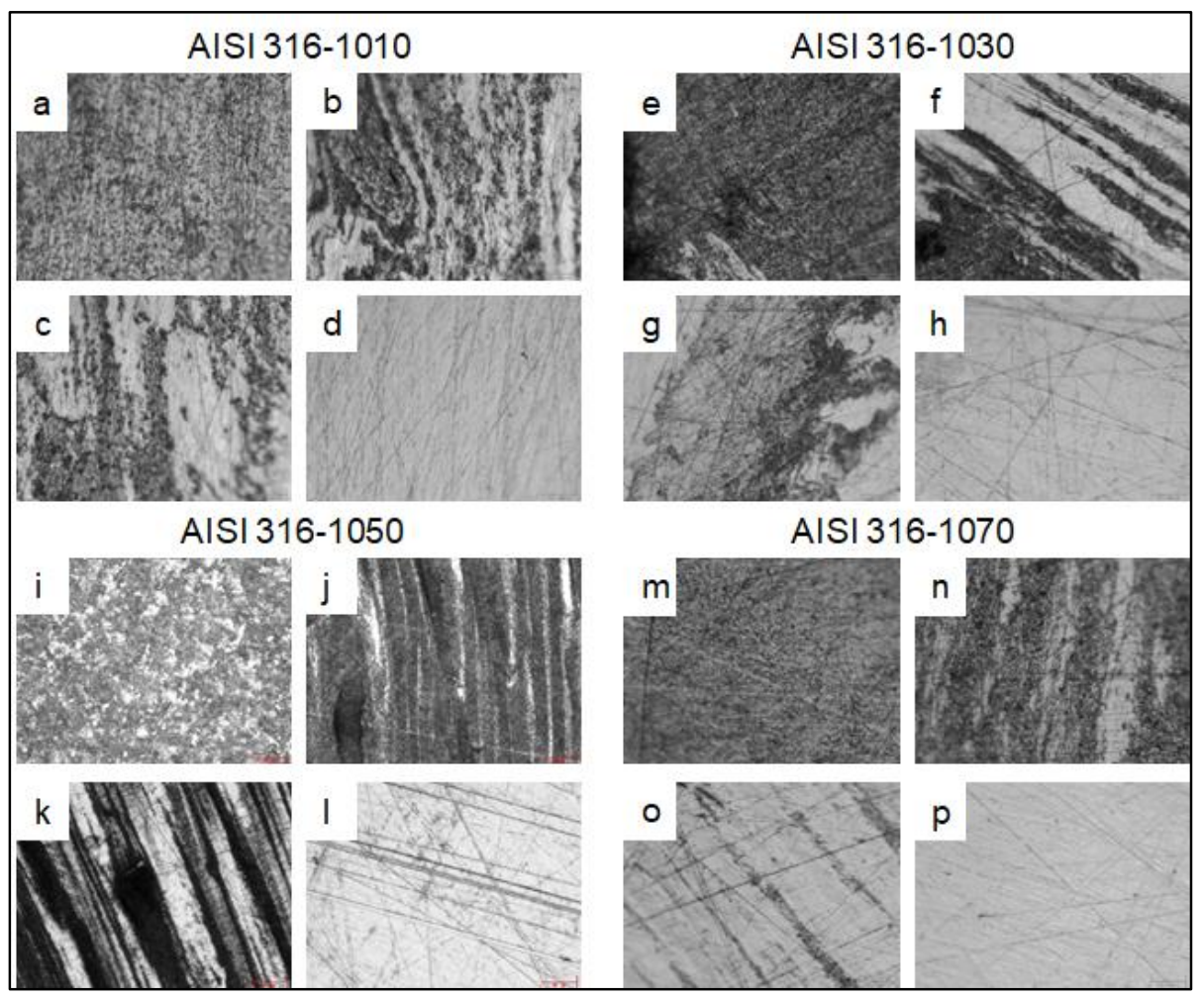

Şekil 6. AISI 316-AISI 10X0 kaynak çiftlerinin optik mikroskop görüntüleri

Şekil 6.i'de beyaz renklerde görünen bölgelerin ferrit, koyu gri-siyah görünen bölgelerin perlit olduğu AISI 1050 çeliği görülmektedir. Yapısında 0,5 oranında karbon içeren AISI 1050 yaklaşık \%35 içeren ferrit, yaklaşık \%65 oranında perlit içermektedir. Şekil 6.j'de karbonlu çelik tarafından kaynak bölgesine girildiğinde ferrit miktarının azaldığı, perlit miktarının arttığı görülmektedir. Ayrıca bloklar halinde görülen beyaz renkler kalıntı ostenit varlığını göstermektedir. Kaynaklı bölge $800-900{ }^{\circ} \mathrm{C}$ gibi yüksek sicaklıklardan aniden $723{ }^{\circ} \mathrm{C}$ nin altına düştüğünde ostenit fazı dönüşemeyip, kalıntı ostenit olarak yüksek gerilimli bölgelerin perlit plakaları arasında kalmasına ve böylece genlemenin de düşük olması ile düşük uzama göstermesine neden olmuştur. Kaynağın orta noktasına gelindiği Şekil 6.k'da yapıda beyaz ve hiç dağlanamamış paslanmaz çeliğin varlığı göze çarpmaktadır. Ayrıca paslanmaz çeliğin yanında perlit miktarı fazlalaşmış, ferrit ise azalmıştır. Şekil 6.l'deyapının tamamen paslanmaz çelik olduğu görülmektedir.
Şekil 6.m'de kaynaksız 1070 karbonlu çeliği, Şekil 6.n'de ise 1070 çeliğinden kaynak bölgesine geçiş görülmektedir. Burada karbonlu çeliğin içerisinde yer yer paslanmaz çeliğin varlığ görülmekte olup kaynağın orta bölgesi olan Şekil 6.o'da ise yapıda daha fazla paslanmaz çelik ve bu çeliğin içerisinde blok blok 1070'in olduğu göze çarpmaktadır. 1070 çeliğinin yüksek miktarda karbon içermesinden dolayı sert olması ve bunun sonucunda 316 paslanmaz çeliğinin 1070 karbonlu çeliğini deforme edememesi sebebiyle malzeme akışının olmadığı düşünülmektedir. Şekil 6.p'de ise 316 paslanmaz çeliği görülmektedir.

\subsubsection{Taramalı Elektron Mikroskobu}

Sürtünme karıştırma kaynağı ile birleştirilen AISI 316-AISI 10X0 çelik çiftlerinin çekme, kayma ve çentik darbe deneyleri sonrası oluşan kırık yüzeyleri taramalı elektron mikroskobu ile görüntülenmiştir. 
Sürtünme Karıştırma Kaynağı ile Birleştirilen AISI 316 Paslanmaz Çelik ve Karbonlu Çelik Çiftlerinin Mekanik Özelliklerinin ve Mikroyapılarının Incelenmesi

\subsubsection{Cekme Deneyi Sonrası Oluṣan Kırık Yüzeylerin SEM Görüntüleri}

Şekil 7'de AISI 316-AISI 10X0 kaynak çiftlerinin çekme deneyi sonrasında oluşan kırık yüzeyleri taramalı elektron mikroskobu ile görüntülenmiştir. AISI 316-AISI 1010 kaynak çiftinde görüldüğü üzere içeriden oluşmaya başlayan çekme boşlukları aracılığıyla malzemedeki iç yüzey alanının düştüğü ve sünek kırılma oluştuğu gözlemlenmiştir. Tane morfolojileri genellikle fiber yapılı olup yüksek miktarda süneklik gösteren tanelerle birlikte klivaja sahip olan tanelerde görülmektedir. Isıdan etkilenen bölge civarında meydana gelen kopma hem kısmen büyümüş ve yeniden kristalleşmiş taneler hem de küçük ve sünen taneler içermektedir.
AISI 316-AISI 1030 kaynak çiftinin SEM analizine baktığımızda, tane içerisinde çukurların oluştuğu görülmektedir. Bu çukurların büyüyerek malzemeyi deformasyona uğrattığı ve kırılmaya maruz bıraktığı düşünülmektedir.

AISI 316-AISI 1050 kaynak çiftinin kırık yüzeyleri incelendiğinde büyümüş taneler görülmektedir. Büyümüş tanelerde sünekligi azalttığı için tanenin şekil değiştirme kapasitesini olumsuz yönde etkiler ve kırılma olayını hızlandırır. Bu çelik çiftinin tane büyüklüğünün genellikle AISI 316-AISI 1010 ve AISI 316-AISI 1030 çelik çiftlerinden daha fazla olduğu görülmektedir. Bunun sonucunda da AISI 316-AISI 1010 ve AISI 316-AISI 1030 çelik çiftlerinden daha az sünek olduğu ve daha çabuk kırıldığı düşünülmektedir.
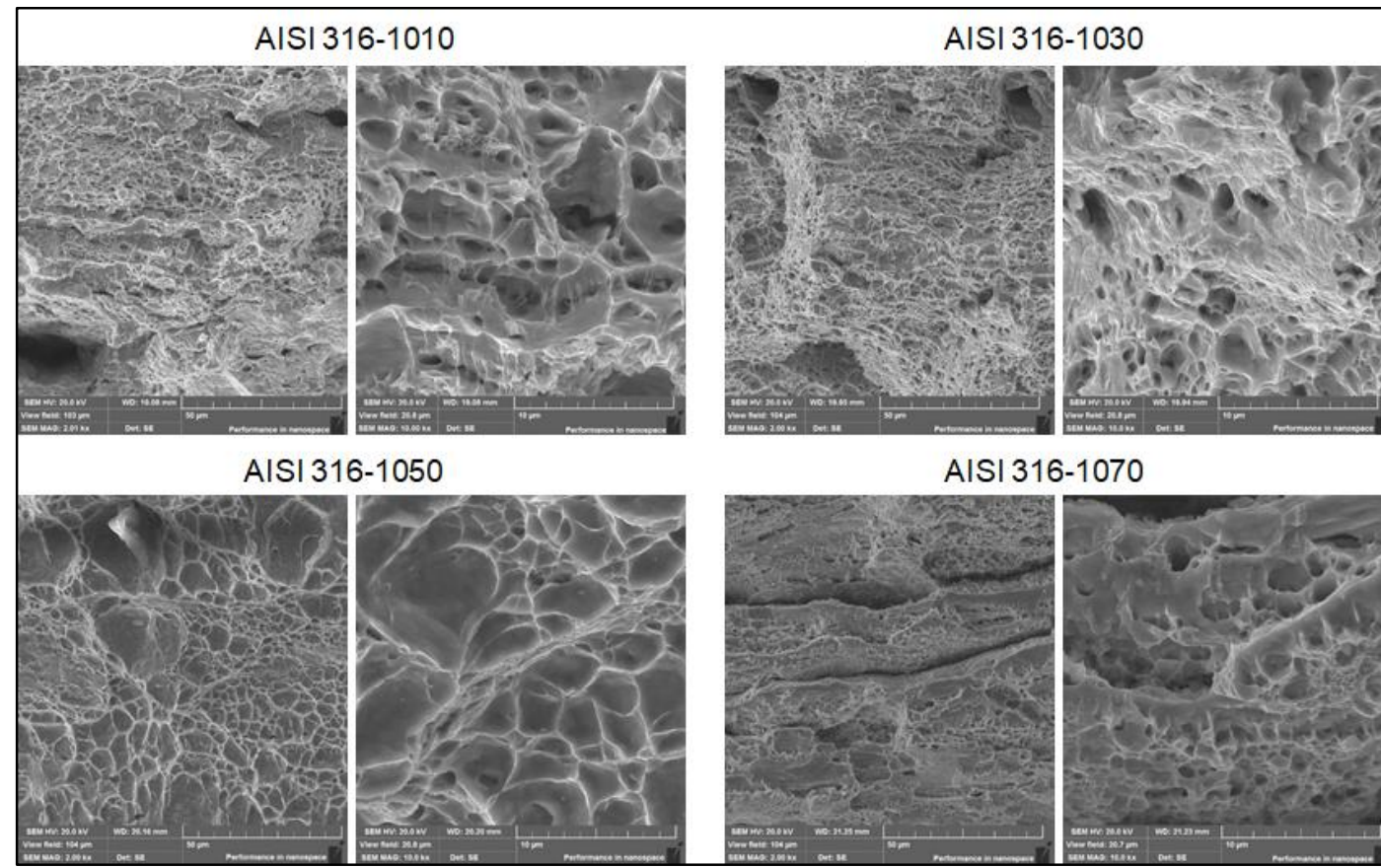

AISI 316-1070
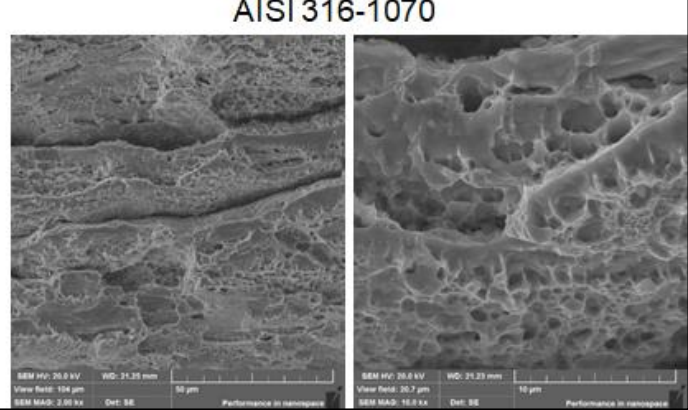

Şekil 7. AISI 316-AISI 10X0 kaynak çiftlerinin çekme deneyi sonrası oluşan kırık yüzeylerinin SEM görüntüleri

AISI 316-AISI 1070 kaynak çiftinin kırık yüzeyleri incelendiğinde, yüksek sertlik ve mukavemetten dolayı kaynak bölgesinde olan daralma diğer çelik çiftlerine nazaran daha az görülmüştür. Yüksek sıcaklıktan dolayı taneler aşırı büyümüş ve soğurken çekmesinden dolayı da gözenek oluşumu gözlemlenmiştir. Delaminasyona bağlı olarak kaynak yüzeyinden $1 \mathrm{~mm}$ içeride karıştırma 1sısından dolayı yüksek sıcaklıkla büyümüş aşırı taneler ve plakanın kalınlığ 1 doğrultusunda aşağı yönlü aşırı büyümüş taneler oluştuğu gözlemlenmiştir. 


\subsubsection{Kayma Deneyi Sonrası Oluşan Kırık Yüzeylerin SEM Görüntüleri}

Şekil 8'de AISI 316-AISI 10X0 kaynak çiftlerinin kayma deneyi sonrasında oluşan kırık yüzeyleri taramalı elektron mikroskobu ile görüntülenmiştir. AISI 316-AISI 1010' da küçük tanelerin etrafında dinamik yeniden kristalleşme ile büyümüş taneler görülmektedir. Çekme boşluklarının birleşerek büyüdüğü ve alan azaltarak düşük genleme ile kısmi sünek şekilde kırıldığı düşünülmektedir.

AISI 316-AISI 1030 çelik çiftine baktığımızda deformasyon çatlakları, sünek taneler, sünek tanelerin dinamik olarak yeniden kristalleşmesi ile büyümüştür. Her birinde çekme boşluğu oluştuğu gözlemlenmiş ve büyüyen çekme boşlukları yüksek çatlak enerjisi oluşturmuştur. Bu ise yapıda sünekgevrek kırılma özelliklerini göstermiştir.

AISI 316-AISI 1050 çelik çiftine baktığımızda, küçük tanelerin yanı sıra blok blok büyük taneler görülmektedir. Yer yer küçük çatlaklarında olduğu, bu çatlakların büyüyerek gevrek kırılmaya neden olduğu düşünülmektedir.

AISI 316-AISI 1070 çelik çiftinde sünek küçük tanelerin etrafında dinamik yeniden kristalleșme ile büyümüş taneler görülmektedir. AISI 1050 de olduğu gibi çatlakların büyüyerek gevrek kırılmalara neden olduğu düşünülmektedir.

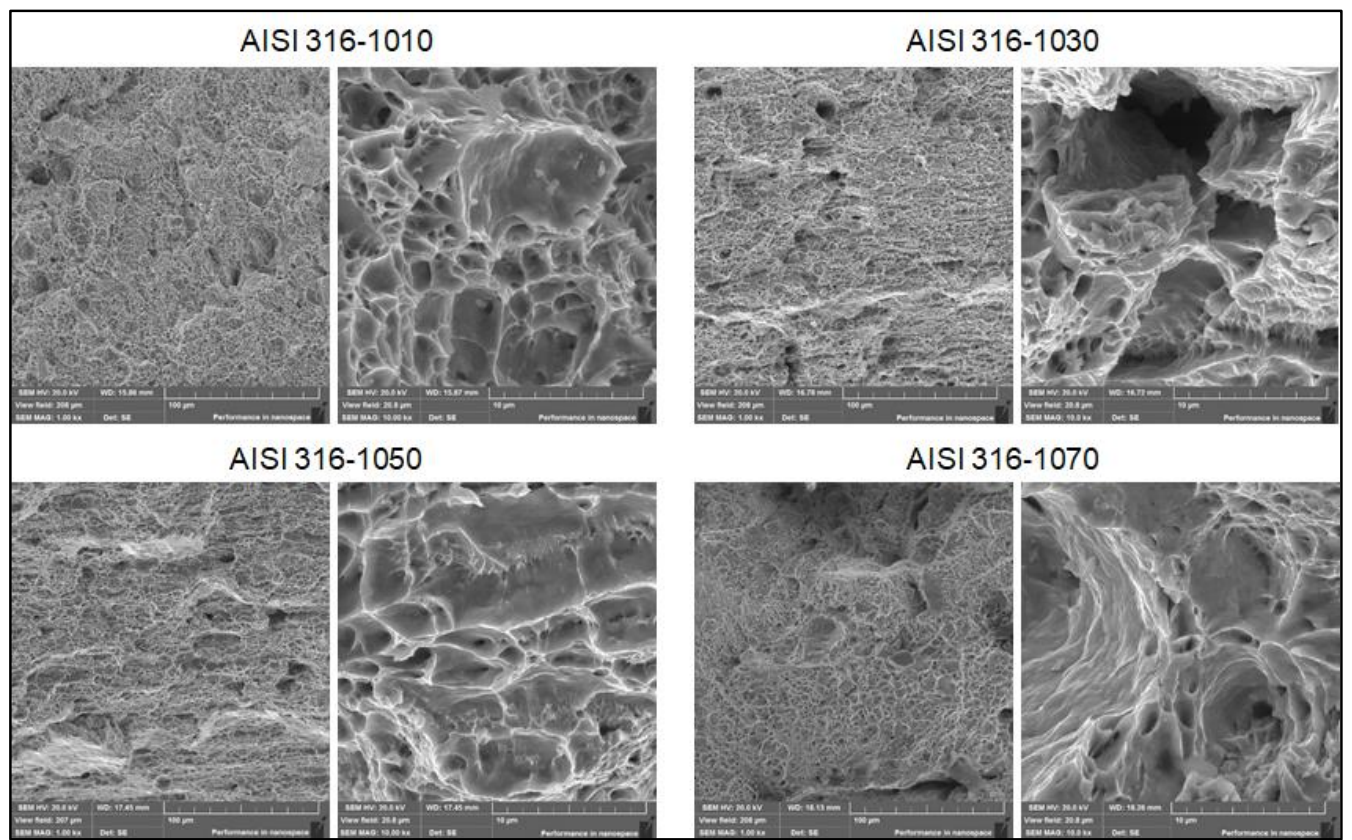

Şekil 8. AISI 316-AISI 10X0 kaynak çiftlerinin kayma deneyi sonrası oluşan kırık yüzeylerinin SEM görüntüleri

\subsubsection{3. Çentik Darbe Deneyleri Sonrası Oluşan Kırık Yüzeylerin SEM Görüntüleri}

Şekil 9'da çentik darbe deneyi sonrası oluşan kırık yüzeylerin SEM görüntüleri görülmektedir.

AISI 316-AISI 1010 çelik çiftinin deformasyonun başlangıcında yüksek enerji ile gevrek tipte kırılma oluşturduğu düşünülmektedir. Daha sonra bu yüksek enerjinin ısıdan etkilenmeyen küçük taneler tarafından absorbe edilerek çatlak ilerlemesini biraz yavaşlattığ 1 ve böylece kırılma enerjisinin yüksek değerlerde olduğu düşünülmektedir.

AISI 316-AISI 1030'da çatlak ilerlerken sürekli küçük taneli yapılara denk gelmiş ve bu ise çatlak 
Sürtünme Karıştırma Kaynağı ile Birleştirilen AISI 316 Paslanmaz Çelik ve Karbonlu Çelik Çiftlerinin Mekanik Özelliklerinin ve Mikroyapılarının İncelenmesi

enerjisini durdurucu yönde rol oynamış ve çekme boşluklarına benzer sünme bölgelerinin oluştuğu gözlemlenmiştir. Çatlak büyüdükten sonra iç yüzeydeki 1sıdan etkilenmiş bölgelere denk gelen çatlak ucunun büyük tanelerin genleyememesi nedeniyle kırılmaya uğradığı düşünülmektedir.

AISI 316-AISI 1050 kaynaklanmış çelik çiftinde, malzemenin sertliğindeki ve mukavemetindeki artıștan dolayı ve yapıda yüksek sıcaklıkla birlikte meydana gelmiş büyük tanelerin zor genlemesinden dolayı darbe enerjisinde de düşüş gözlenmiştir.

AISI 316-AISI 1070 kaynak çiftine baktı̆̆ımızda, darbe enerjisinden sonra etkili olan çatlak enerjisinin, malzemenin mukavemeti ve sertliğinden dolayı gevrek kırılmaya neden olduğu düşünülmektedir.

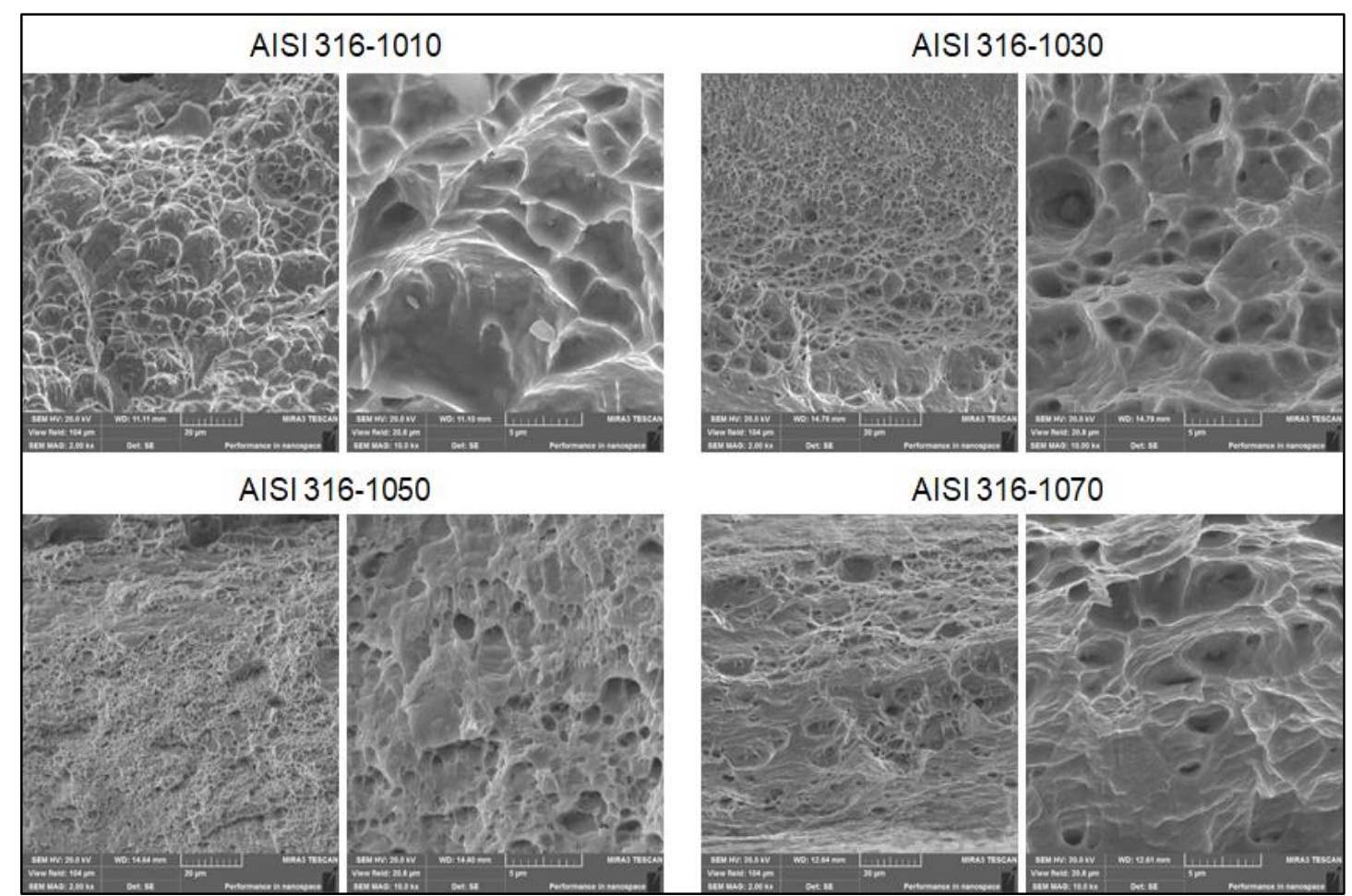

Sekil 9. AISI 316-AISI 10X0 kaynak çiftlerinin çentik darbe deneyi sonrası oluşan kırık yüzeylerinin SEM görüntüleri

\subsection{3. $\mathrm{X}$ Işsını Difraksiyonu}

Şekil 11'de XRD desenlerinden görüldüğü üzere, AISI 1010 ile kaynaklanan 316 paslanmaz çelik, 1010'un ferritik yapısından dolayı HMK kristal kafeste bulunmaktadır. Bu fazda tane büyümesi çok az ve kalıntı östenit miktarı çok düşük seviyededir. Karbon miktarının artması ile YMK kristal kafesi yine $43.8^{\circ}$ 'de (111) piki ile kendini göstermekte ve artan $\mathrm{C}$ oranlarında çok yüksek miktarda YMK kafes yapısı görülmektedir. Bunun sonucu olarak da
316 ostenitik paslanmaz çeliğinin 10X0 karbonlu çelik serisine kaynaklanabilirliğinde karışma problemleri ile birlikte mukavemette ve sertlikte düşüşler gözlenmesi olasıdır. Sertlik çok fazla malzeme yapısından etkilenmezken, özellikle mukavemetin düşmesinin sebebinin kalıntı ostenit miktarındaki artış ve iç gerilmeler olduğu, bunların da yapıda uyumsuzluklara sebep olarak büyük taneküçük tane ayrımını meydana getirdiği düşünülmektedir. 


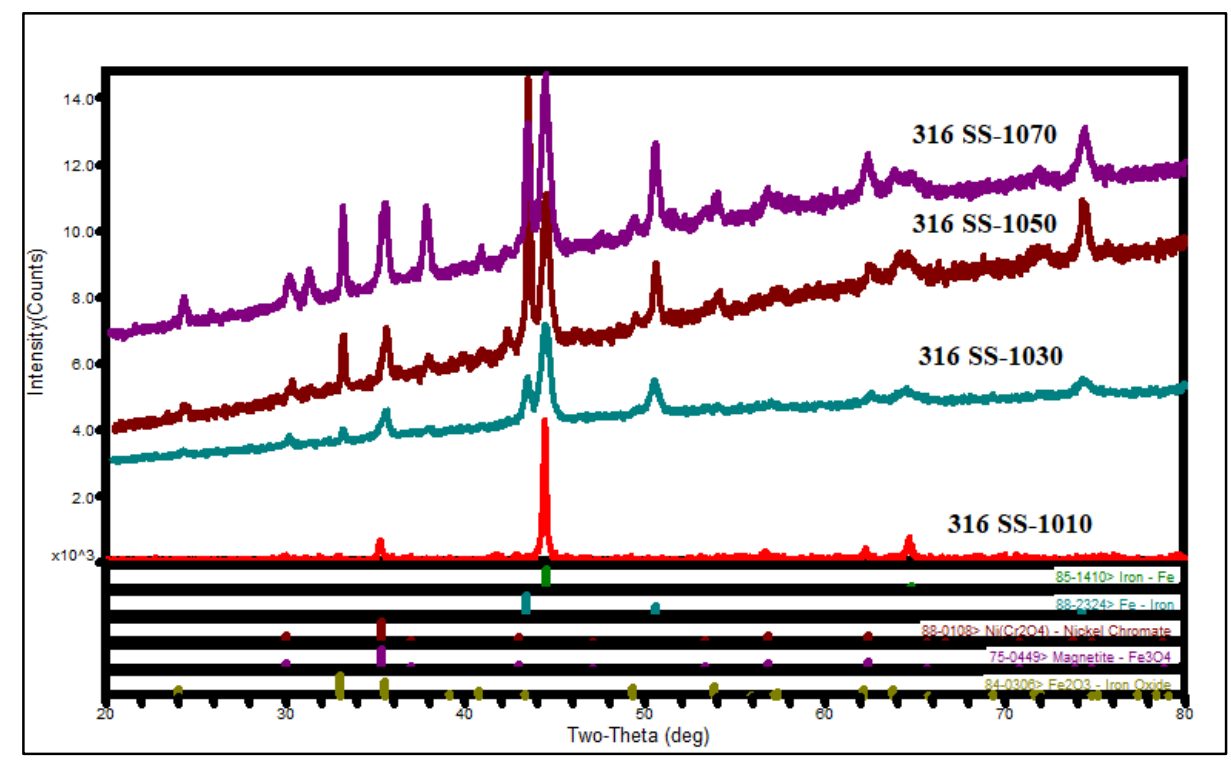

Şekil 10. AISI 316-AISI 10X0 çelik çiftlerinin kaynak bölgelerinden alınmış XRD desenleri

\section{SONUÇLARIN DEĞERLENDİRILMESI}

Bu makalede AISI 316 paslanmaz çeliği ile sade karbonlu çelikler sürtünme karıştırma kaynağ kullanılarak birleştirilmiştir. En uyumlu kaynak çiftini belirlemek amacıyla mekanik ve mikroyapı analizleri yapılmıştır.

Çalışma sonucunda;

1) $710 \mathrm{dev} / \mathrm{dak}$ ve $63 \mathrm{~mm} / \mathrm{dak}$ ilerleme hızında sürtünme karıştırma kaynağı ile birleştirilen AISI 316-AISI $10 X 0$ çelik çiftlerine yapılan mekanik testlerden (çekme, çentik darbe, sertlik, kayma) ve mikroyapı analizlerinden en iyi sonuçların AISI 316-AISI 1010 kaynak çiftinde olduğu ortaya çıkmıştır. Mekanik testlerde en yüksek çekme gerilmesi değeri 618,81 MPa, en yüksek kayma gerilmesi değeri 582,74 MPa ile AISI 316-AISI 1010 çelik çifti için bulunmuştur.

2) Kırılma enerjileri incelendiğinde AISI 316-AISI 1010 'un 19,5 J ile en yüksek kırılma enerjisine sahip olduğu tespit edilmiş, dolayısıyla bu çelik çiftinin diğerlerine göre daha sünek olduğu belirlenmiştir.
3) Mikroyapı analizlerinde SEM ve OM sonuçları irdelendiğinde tane boyutunun ve plakaların delaminasyonunun, malzeme mukavemeti ve sertliğini önemli ölçüde etkilediği görülmektedir. Bu numunelerde özellikle tane büyümesinin olduğu yerlerde düzensizliklerle birlikte mukavemetin de düştüğü gözlemlenmiştir. Küçük tane boyutuna ve sürekli dikişe sahip kaynakların daha yüksek çekme değerlerine sahip olduğu belirlenmiştir.

\section{TEŞEKKÜR}

Bu çalışma, "Paslanmaz Çelik ve Sade Karbonlu Çelik Çiftlerinin Farklı Standartlarda Sürtünme Karıştırmalı Kaynak Yöntemiyle Birleştirilmesi, Mekanik Özelliklerin ve Mikroyapıların İncelenmesi" adlı TÜBİTAK 118M791 numaralı proje kapsamında gerçekleştirilmiştir.

\section{KAYNAKLAR}

1. Cam, G., Mistikoglu, S., 2014. Recent Developments in Friction Stir Welding of Alalloys. Journal of Materials Engineering and Performance, 23(6), 1936-1953. 
2. Thomas, W.M., Threadgill, P.L., Nicholas, E.D., 1999. Feasibility of Friction Stir Welding Steel. Science and Technology of Welding and Joining, 4(6), 365-372.

3. Mishra, R.S., Ma, Z.Y., 2005. Friction Stir Welding and Processing. Materials Science and Engineering R., 50, 1-78.

4. Meran, C., Canyurt, O.E., 2010. Friction Stir Welding of Austenitic Stainless Steels. The Journal of Achievements in Materials and Manufacturing Engineering, 43(1), 432-439.

5. Jafarzadegan, M., Feng, A.H., Abdollah-zadeh, A., Saeid, T., Shen, J., Assadi, H., 2012. Microstructural Characterization in Dissimilar Friction Stir Welding Between 304 Stainless Steel and st37 Steel. Materials Characterization, 74, 28-41.

6. Aktarer, S.M., Sekban, M., Küçükömeroğlu, T., 2015. IF Çeliği ile AA6061 Alaşımının Sürtünme Karıştırma Kaynak Yöntemiyle Birleştirilebilirliği. Kaynak Kongresi IX. Ulusal Kongre ve Sergisi Bildiriler Kitab1, Ankara, 2021 Kasim 2015, 435-445.

7. Reynolds, A.P., Tang, W., Gnaupel-Herold, T., Prask, H., 2003. Structure, Properties, and Residual Stress of 304L Stainless Steel Friction Stir Welds. Scripta Materialia, 48, 1289-1294.

8. Bozkurt, Y., Boumerzoug, Z., 2018. Tool Material Effect on the Friction Stir Butt Welding of AA2124-T4 Alloy Matrix MMC. Journal of Materials Research and Technology, 7(1), 29-38.

9. Basak, H., Kayır, Y., Turkyilmaz, E.H., 2018. Experimental Investigation of the Different Stirring Pin Forms Caused Force and its Effects of Joining on Friction Stir Welding. El-Cezeri Science and Engineering Journal, 4(2), 249-257.

10. Ragu Nathan, S., Balasubramanian, V., Malarvizhi, S., Rao, A.G., 2016. Effect of Tool Shoulder Diameter on Stir Zone Characteristics of Friction Stir Welded HSLA Steel Joints. Transactions of the Indian Institute of Metals, 69(10), 1861-1869.

11. Boz, M., Kurt, A., 2004. The Influence of Stirrer Geometry on Bonding and Mechanical Properties in Friction Stir Welding Process. Materials \& Design, 25, 343-347.
12. Elengovan, K., Balasubramanian, V., 2008. Influences of Tool Pin Profile and Tool Shoulder Diameter on the Formation of Friction Stir Processing Zone in AA6061 Aluminium Alloy. Materials \& Design, 29, 362-373.

13. Sik, A., Erturk, I., Onder, M., 2010. A Study into Effects of Different Parameters on Mechanical Properties in Friction Stir Welding of AA 2024 Aluminium Alloy. Pamukkale University Journal of Engineering Sciences, 16(2), 139-147.

14. Hascalık, A., Caydas, U., Unal, E., Karaca, F., 2007. The Effect of tip Geometry on the Friction Stir Selding of AA 5251 Alloy. Electronic Journal of Machine Technologies, 4, 1-7.

15. Fujii, H., Cui, L., Tsuji, N., Maeda, M., Nakata, K., Nogi, K., 2006. Friction Stir Welding of Carbon Steels. Materials Science and Engineering: A., 429, 50-57.

16. Lienert, T.J., Stellwag, W.L., Grimmet, B.B., Warke, R.W., 2003. Friction Stir Welding Studies on Mild Steel Tool Durability and Steel Microstructure. Supplement to the Welding Journal, 1S-9S.

17. Lakshminarayanan, A.K., 2016. Enhancing the Properties of Friction Stir Welded Stainless Steel Joints Via Multi-criteria Optimization. Archives of Civil and Mechanical Engineering, 16(4), 605-617.

18. Park, S.H.C., Sato, Y.S., Kokawa, H., Okamoto, K., Hirano, S., Inagaki, M., 2003. Rapid Formation of the Sigma Phase in 304 Stainless Steel During Friction Stir Welding. Materials Science, 49, 1175-1180.

19. Meran, C., Kovan, M., Alptekin, A., 2007. Friction Stir Welding of AISI 304 Austenitic Stainless Steel. Materials Science and Engineering Technology, 38(10), 829-835.

20. Bilgin, M.B., Meran, C., 2012. The Effect of Tool Rotational and Traverse Speed on Friction Stir Weldability of AISI 430 Ferritic Stainless Steels. Materials \& Design, 33, 376-383.

21. Cho, H.H., Han, H.N., Hong, S.T., Park, J.H., Kwon, Y.J., Kim, S.H., Steel, R.J., 2011. Microstructural Analysis of Friction Stir Welded Ferritic Stainless Steel. Materials Science and Engineering: A., 528(6), 2889-2894. 
22. Nandan, R., DebRoy, T., Bhadeshia, H.K.D.H., 2008. Recent Advances in Friction-Stir Welding -Process, Weldment Structure and Properties. Progress in Materials Science, 53, 980-1023.

23. Cakır, R., Celik, S., 2018. Effect of Welding Parameters on Microstructure and Mechanical Properties of Friction Stir Welded Al 5754-Cu. El-Cezeri Science and Engineering Journal, 4(1) 82-91.

24. Kimapong, K., Watanabe, T., 2004. Friction Stir Welding of Aluminum Alloy to Steel. Welding Journal, 83(10), 277S-282S.

25. Aghaei, A., Dehghani, K., 2015. Characterizations of Friction Stir Welding of Dissimilar Mone1400 and Stainless Steel 316. International Journal of Advanced Manufacturing Technology, 77, 573-579.

26. Jafarzadegan, M., Feng, A.H., Abdollah-zadeh, A., Saeid, T., Shen, J., Assadi, H., 2013. Microstructure and Mechanical Properties of a Dissimilar Friction Stir Weld Between Austenitic Stainless Steel and Low Carbon Steel. Journal of Materials Science and Technology, 29(4), 367-372.

27. Sharma, G., Dwivedi, D.K., 2017. Study on Microstructure and Mechanical Properties of Dissimilar Steel Joint Developed Using Friction Stir Welding. International Journal of Advanced Manufacturing Technology, 88, 1299-1307. 
